\title{
Correlation of HbA1c levels with Triglyceride, LDL and HDL levels in Type 2 Diabetes Mellitus Patients
}

\author{
Tri Prasetyorini ${ }^{1}$, Cindy $^{2}$, Salbiah ${ }^{3}$ \\ ${ }^{1,2,3}$ Health Polytechnic of Ministry of Health Jakarta III, Bekasi, Indonesia \\ Email: tprasetyorini@gmail.com
}

\begin{abstract}
Diabetes mellitus (DM) is a group of metabolic diseases with characteristics of increased blood glucose levels that occur due to abnormal insulin secretion, insulin action or both. It is necessary to monitor long-term glycemic status by measuring $\mathrm{HbA} 1 \mathrm{c}$ levels to determine the quality of long-term blood glucose control. People with Type 2 DM are more at risk of suffering from cardiovascular disease characterized by dyslipidemia, with a characteristic description of high plasma triglyceride levels, elevated LDL levels and decreased HDL levels. The purpose of this study was to determine the relationship between $\mathrm{HbA} 1 \mathrm{c}$ levels and levels of triglycerides, LDL and HDL. This study was an analytic observational study using a cross-sectional design. Data on each variable is secondary data obtained from patients with Type 2 DM at Jakarta Friendship Hospital for the period January-December 2018. The research sample used was 97 data of Type 2 DM patients. Chi-Square test showed an association between $\mathrm{HbA1c}$ levels and triglyceride levels with a value of $p=$ $0.046(<0.05)$, there was a relationship between HbA1c levels and LDL levels with $p=$ $0.742(p>0.05)$, and there was a relationship between HbA1c levels and HDL levels with $p$ $=0.241(p>0.05)$. The conclusion obtained in this study is that there is a significant relationship between $\mathrm{HbA1c}$ levels and triglyceride levels and there was no significant relationship between $\mathrm{HbA1c}$ levels and LDL and HDL levels.
\end{abstract}

Keywords: Type 2 Diabetes Mellitus, triglyceride, LDL, HDL.

\section{A. INTRODUCTION}

Diabetes mellitus (DM) is a group of metabolic diseases characterized by an increase in blood glucose levels that occurs due to abnormal insulin secretion, insulin action or both (PERKENI, 2015). The results of Basic Health Research (RISKESDAS) in 2013 showed the proportion of people with DM in Indonesia aged 15 years and over amounted to 6.9\% (Ministry of Health, 2014). According to the American Disease Association (ADA) about $90 \%-95 \%$ of the entire diabetic population is Type $2 \mathrm{DM}$ caused by insulin deficiency and insulin resistance (American Disease Association, 2017). At present the international committee and the ADA have recommended $\mathrm{HbA1c}$ for diagnosing $\mathrm{DM}$ (WHO, 2011). $\mathrm{HbA1c}$ is a bond between hemoglobin and glucose. HbA1c is normal in blood between $4-6 \%$ of blood sugar. If the level is more than $7 \%$, then it needs to be treated with insulin or anti-diabetes drugs (Suprihatini, 2017).

Good blood glucose levels cannot yet illustrate that blood glucose regulation is already good. Long-term glycemic status monitoring for DM sufferers is necessary by measuring $\mathrm{HbA1c}$ levels. Measurement of $\mathrm{HbA1c}$ levels can be used to determine the quality of long-term blood glucose control between 2 to 3 months (Suprihatini, 
2017). According to The United Kingdom Prospective Diabetes Study, a 1\% decrease in $\mathrm{HbA} 1 \mathrm{c}$ reduces the risk of diabetes-related death by $21 \%, 14 \%$ for myocardial infarction, and $37 \%$ of macrovascular complications of diabetes (Permatasari, Sudargo, \& Purnomo, 2015). DM if not managed properly will cause complications that are divided into macrovascular complications that will affect the heart and blood vessels and microvascular complications that will affect the eyes, kidneys and nerves (Jabeen et al., 2013). Patients with Type 2 DM are more at risk of suffering from cardiovascular disease which is characterized by dyslipidemia, with characteristic features of high plasma triglyceride levels, increased LDL levels and decreased HDL levels (Charitha et al., 2013).

Research conducted previously by Loei, Pandelaki \& Mandang in 2013 showed no significant relationship between $\mathrm{HbA1c}$ levels with total cholesterol levels with a correlation value of 0.227 and $\mathrm{p}$ count $=1.461 \mathrm{a}>0.05$, there was no significant relationship between $\mathrm{HbA1c}$ levels with triglyceride levels with a correlation value of 0.792 and $p$ count $=0.069 a>0.05$, there is no significant relationship between $\mathrm{HbA1c}$ levels with LDL levels with a correlation value of 0.733 and $\mathrm{p}$ count $=0.116 \mathrm{a}>0.05$ and there is no significant relationship between levels $\mathrm{HbA1c}$ with HDL levels with a correlation value of 0.473 and $\mathrm{p}$ count $=0.514 \mathrm{a}>0.05$. Based on this background, this study was again conducted by not including DM patients with dyslipidemia therapy (statins, niacin and fibrates) as a study sample because dyslipidemia therapy is one of the confounders of lipid levels in DM patients and in this study did not examine the relationship of total cholesterol levels with $\mathrm{HbA1c}$ levels due to lipids that influence the incidence of CHD in patients with Type 2 DM are triglycerides, LDL and HDL.

\section{B. METHOD}

This research was conducted at the Jakarta Friendship Center General Hospital. When the study was conducted in February 2019 - May 2019. The design of this study used cross sectional observational analytic methods with a population of all examination results of type 2 DM patients seeking treatment at the Jakarta Friendship Center General Hospital in January 2018 - December 2018 and samples in this study were the results of the examination of $\mathrm{HbA1c}$, triglycerides, LDL and HDL type 2 DM patients seeking treatment at the Jakarta Friendship Center General Hospital for the period January 2018 - December 2018 as many as 95 samples.

\section{RESULTS AND DISCUSSION}

The results of research on HbA1c levels with triglycerides, LDL and HDL in Type 2 DM patients obtained from the laboratory examination results at the Friendship Hospital in Jakarta can be described as follows: 




Figure 1 Frequency Distribution of Patients with Type 2 DM Patients Based on Gender in Jakarta Friendship Hospital Period January-December 2018

Based on Figure 1 depicting the frequency distribution of characteristics according to sex from 97 data of patients with Type 2 DM studied 44 people $(45.5 \%)$ men and 53 people (54.6\%) women. Women are more at risk of diabetes because physically they have the opportunity to increase body mass index greater (Fatimah, 2015). Especially obese women have a higher risk for impaired insulin sensitivity because it is influenced by the hormone estrogen during the menstrual cycle, pregnancy, and perimenopause which causes body fat distribution to be easily accumulated. In addition, if there is an increase in estrogen levels, the secretion of the hormone epinephrine will also increase (Pardede et al, 2017).



Figure 2 Frequency Distribution of Patients with Type 2 DM Patients Based on Age Classification in Jakarta Friendship Hospital Period January-December 2018 Source: Balitangkes RI Ministry of Health (2013)

Based on Figure 2 illustrates the frequency distribution of characteristics according to the age classification of Type 2 DM sufferers mostly suffered by patients with the age group 45-64 years as many as 65 people $(67.0 \%)$. The youngest patient with Type 2 DM is 30 years old and the oldest age is 80 years. At the age of over 45 years a person is more often affected by DM because the level of insulin sensitivity begins to decrease so that blood sugar levels that should enter the cells will remain in the bloodstream which causes blood sugar levels to rise. Type $2 \mathrm{DM}$ appears at the age of over 45 years because at that age many changes, especially in 
the pancreatic organs that produce insulin. Each increase in age results in diminished pancreatic function and insulin action (Santosa et al., 2017).

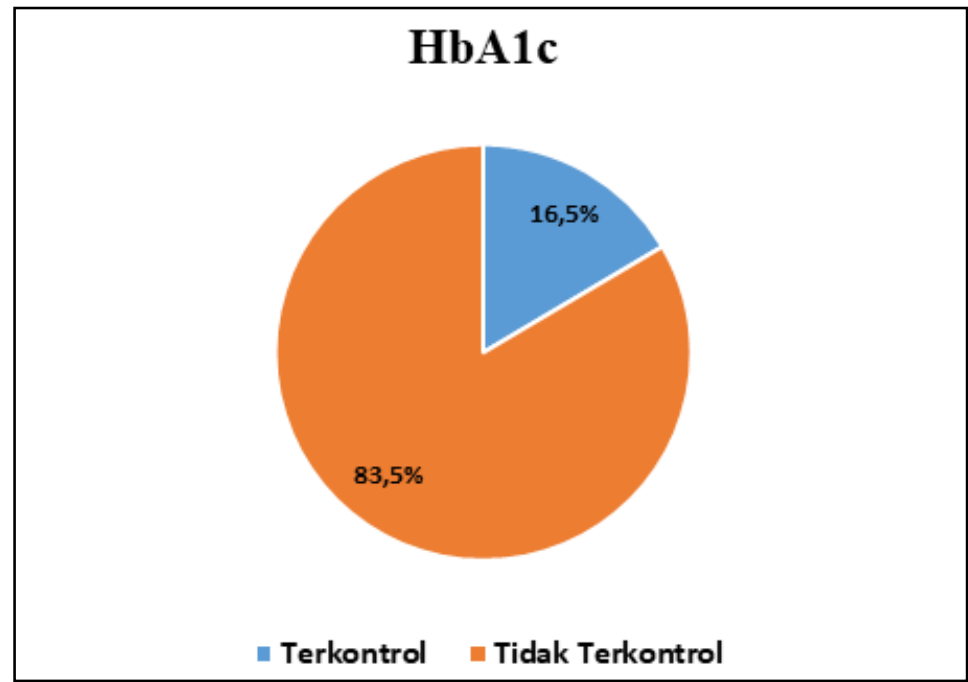

Figure 3 Frequency Distribution of Patients with Type 2 DM Controlled and Not Controlled Based on HbA1c Levels in the Jakarta Friendship Hospital in the January-December 2018 Period

Based on Figure 3 illustrates the frequency distribution of DM type 2 controlled and uncontrolled based on levels. The results showed that from 97 samples, patients with Type $2 \mathrm{DM}$ who were controlled based on HbA1c levels were 16 people $(16.5 \%)$ and those who were not controlled were 81 people $(83.5 \%)$. Not achieving the DM control target can be caused by several things, namely poor absorption of education, not making eating arrangements or not doing exercise kali 3 times a week with a frequency of $>30$ minutes (Putri \& Isfandiari, 2013).

Table 1 Results of Descriptive Analysis of HbA1c, Triglyceride, LDL and HDL Levels in Type 2 DM Patients in Jakarta Friendship Hospital Period JanuaryDecember 2018

\begin{tabular}{cccc}
\hline Variable & Mean & SD & Minimal-Maximal \\
\hline HbA1c & 9,78 & 3,0705 & $4,3-21,9$ \\
Triglyceride & 159,39 & 94,522 & $43-687$ \\
LDL & 110,86 & 45,989 & $24-307$ \\
HDL & 34,37 & 15,477 & $5-90$ \\
\hline
\end{tabular}

Based on Table 4.1 the results of the study found the average levels of $\mathrm{HbA1c}$ patients with Type $2 \mathrm{DM}$ who were respondents of the study were $9.78 \%$. The lowest $\mathrm{HbA} 1 \mathrm{c}$ level is $4.3 \%$ and the highest is $21.9 \%$. The results showed the average triglyceride levels of study respondents were $159.39 \mathrm{mg} / \mathrm{dL}$. The lowest triglyceride level is $43 \mathrm{mg} / \mathrm{dL}$ and the highest triglyceride level is $687 \mathrm{mg} / \mathrm{dL}$. The results showed an average LDL level of research respondents was $110.86 \mathrm{mg} / \mathrm{dL}$. the lowest LDL level is $24 \mathrm{mg} / \mathrm{dL}$ and the highest LDL level is $307 \mathrm{mg} / \mathrm{dL}$. The results 
showed an average of HDL levels of research respondents was $34.37 \mathrm{mg} / \mathrm{dL}$. the lowest HDL level is $5 \mathrm{mg} / \mathrm{dL}$ and the highest HDL level is $90 \mathrm{mg} / \mathrm{dL}$.

Insulin deficiency that occurs in Type 2 DM causes lipolysis and the release of fatty acids into the blood circulation which results in increased concentration of free fatty acids in the blood. Excess fatty acids in the blood trigger changes in fatty acids into phospholipids and cholesterol in the liver as a result of fat metabolism. Phospholipids, cholesterol and excessive triglycerides are formed the same time in the liver which will then be released in the blood in the form of lipoproteins. As a result an increase in lipoprotein (Hall, 2016).

Table 2 Cross Table of HbA1c Levels with Triglyceride Levels in Patients with Type 2 DM in Friendship Hospital Jakarta Period January - December 2018

\begin{tabular}{|c|c|c|c|c|c|c|c|c|c|c|}
\hline \multirow{2}{*}{\multicolumn{2}{|c|}{ Check Up Result }} & \multicolumn{8}{|c|}{ Triglyceride levels } & \multirow{3}{*}{ P Value } \\
\hline & & \multirow{2}{*}{$\begin{array}{c}\text { Normal } \\
\mathrm{N}\end{array}$} & \multicolumn{3}{|c|}{$\begin{array}{l}\text { A little } \\
\text { high }\end{array}$} & \multicolumn{2}{|l|}{ High } & \multicolumn{2}{|c|}{$\begin{array}{l}\text { Very } \\
\text { High }\end{array}$} & \\
\hline & & & $\%$ & $\mathrm{~N}$ & $\%$ & $\mathrm{~N}$ & $\%$ & $\mathrm{~N}$ & $\%$ & \\
\hline \multirow{2}{*}{$\begin{array}{l}\text { HbA1c } \\
\text { Levels }\end{array}$} & Controlled & 15 & 15,5 & 1 & 1,0 & 0 & 0 & 0 & 0 & \multirow[b]{2}{*}{0,046} \\
\hline & $\begin{array}{c}\text { Not } \\
\text { controlled }\end{array}$ & 46 & 47,4 & 19 & 19,6 & 15 & 15,5 & 1 & 1,0 & \\
\hline
\end{tabular}

Based on Table 2 the results of the cross table analysis between HbA1c levels with triglyceride levels in patients with Type $2 \mathrm{DM}$ obtained group results with controlled HbA1c levels with normal triglyceride levels of 15 people $(15.5 \%)$. Controlled HbA1c levels with rather high triglyceride levels of one person $(1.0 \%)$. Uncontrolled $\mathrm{HbA1c}$ levels with normal triglyceride levels were 46 people (47.4\%). Uncontrolled $\mathrm{HbA1c}$ levels with triglyceride levels were rather high as many as 19 people (19.6\%). Uncontrolled HbA1c levels with high triglyceride levels of 15 people (15.5\%). Uncontrolled HbA1c levels with very high triglyceride levels of one person $(1.0 \%)$. Not found results of respondents who have controlled $\mathrm{HbA1c}$ levels with high and very high triglyceride levels.

Chi Square test results with HbA1c levels with triglyceride levels in patients with Type 2 diabetes obtained $p$ value $=0.046(p<0.05)$ which indicates that there is a statistically significant relationship between $\mathrm{HbA} 1 \mathrm{c}$ levels with triglyceride levels. Insulin resistance that occurs in Type $2 \mathrm{DM}$ results in increased blood sugar levels and increased lipoprotein lipase action. When the action of lipoprotein lipase increases, triglycerides are increasingly hydrolyzed because nothing inhibits the action of these hormones which will result in high levels of triglycerides in the blood (Wu \& Parhofer, 2014). 
Table 3 Cross Table of HbA1c Levels with LDL Levels in Patients with Type 2 diabetes at the Friendship Hospital in Jakarta Period January-December 2018

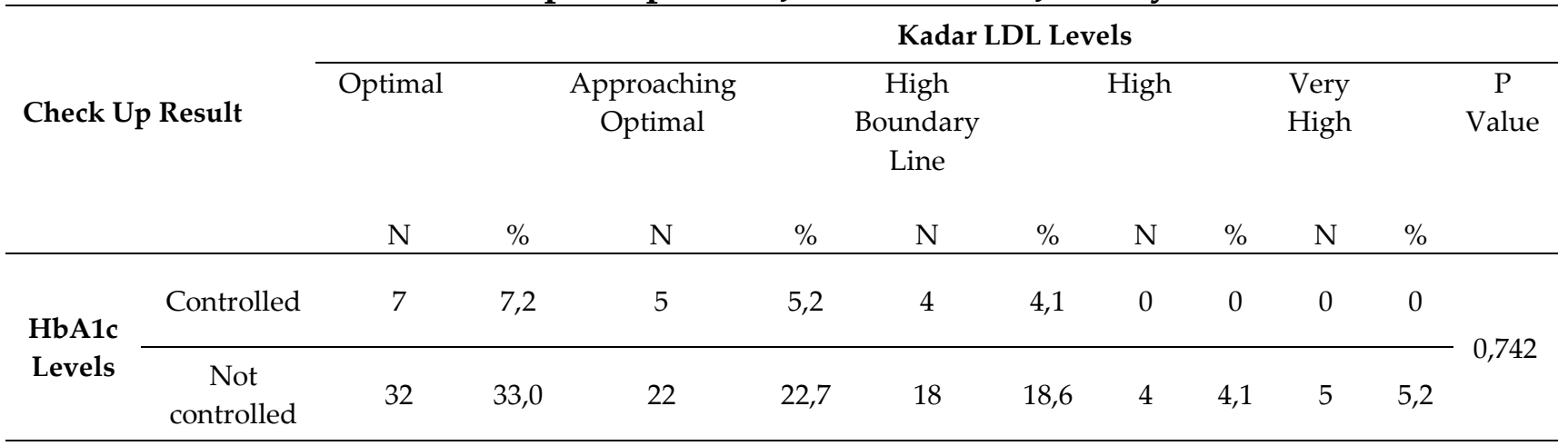

Based on Table 3 the results of cross table analysis between $\mathrm{HbA1c}$ levels with LDL levels in patients with Type 2 DM obtained the results of groups with controlled HbA1c levels with optimal LDL levels of seven people (7.2\%). Controlled $\mathrm{HbA1c}$ levels with near optimal LDL levels were five people (5.2\%). The HbA1c level was controlled with four LDL levels near the high border line (4.1\%). Uncontrolled $\mathrm{HbA1c}$ levels with optimal LDL levels were 32 people (33.0\%). Uncontrolled $\mathrm{HbA} 1 \mathrm{c}$ levels with approaching optimal LDL levels were 22 people $(22.7 \%)$. Uncontrolled $\mathrm{HbA1c}$ levels with high borderline LDL levels were 18 people $(18.6 \%)$. Uncontrolled $\mathrm{HbA1c}$ levels with high LDL levels as many as four people $(4.1 \%)$. Uncontrolled HbA1c levels with very high triglyceride levels of five people (5.2\%). Not found results of respondents who have controlled $\mathrm{HbA1c}$ levels with high and very high LDL levels.

Chi Square test results with $\mathrm{HbA1c}$ levels with LDL levels in patients with Type 2 diabetes obtained $p$ value $=0.742(p>0.05)$ which indicates that there is no statistically significant relationship between $\mathrm{HbA1c}$ levels with LDL levels:

Table 4 Cross Table of HbA1c Levels with HDL Levels in Patients with Type 2 diabetes at the Friendship Hospital in Jakarta Period January-December 2018



Based on Table 4 the results of the cross table analysis between HbA1c levels with HDL levels in patients with Type 2 DM obtained the results of groups with controlled $\mathrm{HbA1c}$ levels with low HDL levels of nine people (9.3\%). HbA1c levels were controlled with normal HDL levels in six people (6.2\%). Controlled HbA1c levels with high HDL levels of one person (1.0\%). Uncontrolled HbA1c levels with low HDL levels were 60 people (61.9\%). Uncontrolled HbA1c levels with normal HDL levels were 15 people (15.5\%). Uncontrolled HbA1c levels with high HDL levels as many as six people $(6.2 \%)$. 
Chi Square test results with $\mathrm{HbA1c}$ levels with HDL levels in patients with Type 2 DM obtained $p$ value $=0.241(p>0.05)$ which indicates that there is no statistically significant relationship between $\mathrm{HbA1c}$ levels with HDL levels. In patients with Type 2 diabetes can occur changes in fat metabolism as a result of decreased insulin action which results in increased lipolysis in the tissue and decreased lipoprotein lipase activity in the blood so that blood lipid levels increase (Hall, 2016). Decreased lipoprotein lipase activity also results in changes in VLDL to IDL being disrupted, so that VLDL settles in the liver in the form of fat infiltration (Roslizawaty et al., 2016). The insignificant results in this study can be influenced by confounding factors such as obesity especially those that are central, increased calorie intake or a diet high in saturated fat and low in carbohydrates, lack of exercise, and genetic factors are also very influential in this regard (Fauziah, 2012).

\section{CONCLUSION}

Most people with Type 2 diabetes are 54.6\% women. Most Type 2 DM sufferers occur at age 45-64 years as much as $67.0 \%$. Most HbA1c levels of Type 2 DM sufferers are uncontrolled HbA1c levels as much as $83.5 \%$. The mean HbA1c level for people with Type 2 diabetes is $9.78 \%$. The average triglyceride level of patients with Type 2 diabetes is $159.39 \mathrm{mg} / \mathrm{dL}$. The mean LDL level of patients with Type 2 diabetes is $110.86 \mathrm{mg} / \mathrm{dL}$. The mean HDL level of patients with Type 2 diabetes is $34.37 \mathrm{mg} / \mathrm{dL}$. There is a significant relationship between HbA1c levels with triglyceride levels in patients with Type 2 diabetes. There is no significant relationship between HbA1c levels with LDL levels in patients with Type 2 diabetes. There is no significant relationship between HbA1c levels with HDL levels in patients with Type 2 diabetes.

\section{REFERENCES}

1. American Diabetes Association. (2017). Standard of Medical Care in Diabetes. The Journal of Clinical and Applied Research and Education.

2. Charitha, B., Senghor, A. R., Shivashekar, M., \& William, E. (2013). Glycated Hemoglobin as a Dual Marker: In Control of Glycemic Status and Diabetic Dyslipidemia. International Journal of Pharmaceutical and Clinical Research,5(3), 111-113.

3. Balitbangkes Kementerian Kesehatan RI. (2013). Riset Kesehatan Dasar (RISKESDAS) 2013. Jakarta: Kementerian Kesehatan RI.

4. Fatimah, R. N. (2015). Diabetes Melitus Tipe 2. Journal of Majority, 4(5), 93-101.

5. Hall, J. E. (2016). Textbook of Edical Physiology 13 th Edition. Philadelphia: Elsheiver.

6. Hartini, S. (2017). Hubungan HBA1c terhadap Kadar Glukosa Darah pada Penderita Diabetes Mellitus di RSUD. Abdul Wahab Syahranie Samarinda. Husada Mahakam: Jurnal Kesehatan, 4(3).

7. Kementerian Kesehatan RI. (2013). Situasi dan Analisis Diabetes. Info DATIN Pusat Data dan Informasi Kementeian Kesehatan RI. 
8. Pardede, T. E., Rosdiana, D., \& Christianto, E. (2017). Gambaran Pengendalian Diabetes Melitus Berdasarkan Parameter Indeks Massa Tubuh dan Tekanan Darah di Poli Rawat Jalan Penyakit Dalam RSUD Arifin Achmad Pekanbaru (Doctoral dissertation, Riau University).

9. PERKENI. (2015). Konsensus Pengelolaan dan Pencegahan Diabetes Melitus Tipe 2 di Indonesia 2015. Jakarta: PB PERKENI.

10. Permatasari, S. M., Sudargo, T., \& Purnomo, L. B. (2015). Estimasi asupan indeks glikemik dan beban glikemik dengan kontrol gula darah pasien diabetes melitus tipe 2. Jurnal Gizi Klinik Indonesia, 12(2), 45-53.

11. Putri, N. H. K., \& Isfandiari, M. A. (2013). Hubungan empat pilar pengendalian dm tipe 2 dengan rerata kadar gula darah. Jurnal Berkala Epidemiologi, 1(2), 234243.

12. Santosa, A., Trijayanto, P. A., \& Endiyono, E. (2017). Hubungan Riwayat Garis Keturunan dengan Usia Terdiagnosis Diabetes Melitus Tipe II. URECOL, 1-6.

13. WHO. 2011. Use of Glycated Haemoglobin (HbA1c) in the Diagnosis of Diabetes Mellitus Abbreviated. Switzerland: WHO.

14. Widiningrum, dkk. 2012. Hubungan antara Kontrol Glikemik dengan Kadar Profil Lipid (Pasien Diabetes Melitus Tipe II Rawat Inap dan Rawat Jalan di RSUD Adhyatma Periode 1 Januari - 31 Desember 2013). Semarang.

15. Widiningrum, N. F. (2015). Hubungan Antara Kontrol Glikemik Dengan Profil Lipid (Pasien Diabetes Melitus Tipe II Rawat Inap dan Rawat Jalan di RSUD Adhyatma Periode 1 Januari-31 Desember 2013) (Doctoral Dissertation, UNIMUS).

16. Wu, L., \& Parhofer, K. G. (2014). Diabetic Dyslipidemia. Metabolism Clinical and Experimental, 63, 1469-1479. 